\title{
Modern Editions Cited
}

Dai Mingyang 戴明揚, ed. Xi Kang ji jiaozhu 甃康集校注. Beijing: Renmin wenxue chubanshe, 1962.

Lu Xun 鲁迅, ed. Xi Kang ji 甃康集. Hong Kong: Xinyi chubanshe, 1967.

Wen xuan 文選. Xiao Tong 萧統, ed. With commentary by Li Shan 李善. Shanghai: Shanghai guji chubanshe, 1986. 